Original Research Article

\title{
Study of lipid and non-lipid effects of statins in hypertensive patients
}

\author{
Shashikala E. ${ }^{1}{ }^{*}$, Raghawa Rao B. N. V. ${ }^{2}$
}

${ }^{1}$ Department of Pharmacology, Gandhi Medical College Hospital, Hyderabad, Telangana, India

${ }^{2}$ Department of Medicine, Gandhi Medical College/Gandhi Hospital, Hyderabad, Telangana, India

Received: 14 August 2016

Revised: 20 September 2016

Accepted: 26 September 2016

\section{*Correspondence to:}

Dr. Shashikala E.

Email:

drvijayragava@gmail.com

Copyright: () the author(s), publisher and licensee Medip Academy. This is an openaccess article distributed under the terms of the Creative Commons Attribution NonCommercial License, which permits unrestricted noncommercial use, distribution, and reproduction in any medium, provided the original work is properly cited.

\begin{abstract}
Background: Hypertension is one of the commonest diseases affecting the mankind which is associated with endothelial dysfunction and left ventricular dysfunction and hence the study is aimed to observe the effects of statins on endothelial and left ventricular dysfunction.
\end{abstract}

Methods: 15 hypertensive patients were given atorvastatin for 4 weeks and compared with sex and aged matched 15 controls after a detailed Clinical history, clinical examination, biochemical investigations, chest X-ray, electrocardiogram, echocardiogram and Doppler study of brachial artery.

Results: Both study group and control group consisted of 10 males and 5 females who have dyslipidemia, endothelial and ventricular dysfunction. After a 4 weeks of study, in study group, flow mediated brachial artery diameter (FMD\%) increased significantly $(11.39 \%, \mathrm{P}<0.01)$ from $7.37 \%$ to $18.76 \%$, mean LV systolic function (EF) improved significantly $(10.73 \%, \mathrm{P}:<0.01)$ from $54.6 \%$ to $60.65 \%$, LV diastolic function was normalized in $7(46.67 \%)$ and improved in $5(33.33 \%)$ patients, the mean systolic and diastolic BP decreased significantly $(12.03 \%, \quad \mathrm{P}<0.01,10.29 \%, \mathrm{P}<0.01)$ from $149.66 \mathrm{mmHg}$ to $131.66 \mathrm{mmHg}$ and from $90.66 \mathrm{mmHg}$ to $81.33 \mathrm{mmHg}$ respectively, while in control group FMD increased marginally (1.07\%) from $7.50 \%$ to $8.57 \%$, LV EF marginally improved $(1.47 \%)$ to $54.86 \%$ from $54.06 \%$; no improvement in diastolic dysfunction, mean systolic and diastolic BP decreased marginally $(6.25 \%, 0.74 \%)$ from $149.33 \mathrm{mmHg}$ to $140 \mathrm{mmHg}$ and from $90.33 \mathrm{mmHg}$ to $89.66 \mathrm{mmHg}$ respectively.

Conclusions: Statins improve not only lipid profile but also endothelial and LV functions which resulted in significant reduction of systolic and diastolic BP. Hence it is reasonable to treat all hypertensive patients with statins besides concurrent hypertension treatment.

Keywords: Atorvostatin, Endothelial dysfunction, Hypertension, Lipid and non-lipid effects, LV dysfunction

\section{INTRODUCTION}

Hypertension is one of the most important public health problems worldwide and if left untreated, $50 \%$ die of CAD, $33 \%$ die of stroke and $10-15 \%$ die of renal failure. ${ }^{1}$

These vascular complications of the Hypertension are mainly due to the damage to vascular endothelium (endothelial dysfunction) caused by shear stress of Hypertension which is the initial event in atherosclerotic process. Hence the present study is aimed at observing the association of the essential hypertension with endothelial dysfunction and left ventricular dysfunction which are assessed noninvasively and to evaluate the effects of statins (non-lipid effects) on endothelial and left ventricular dysfunction besides their conventional effect on lipid profile.

\section{METHODS}

Hypertensive is diagnosed when SBP is $\geq 140 \mathrm{~mm} \mathrm{Hg}$ and or DBP is $\geq 90 \mathrm{~mm} \mathrm{Hg}$ as per JNC-VII criteria, 2003 . $^{2}$ Patients with Secondary hypertension, Diabetes mellitus, Hyperlipidemia, Ischemic heart disease and history of smoking were excluded from the study. 
After consent from each patient, a detailed Clinical history, Clinical examination, Biochemical investigations (blood sugar, serum creatinine, serum electrolytes and lipid profile), Chest X-ray, Electrocardiogram, Echocardiogram for left ventricular function(systolic and diastolic) and Doppler study of brachial artery for endothelial function(as described by Celemajor et al) were done. ${ }^{3,4}$ The patients in Study group were received atorvastatin $(10-20 \mathrm{mg} /$ day) for 4 weeks with concurrent hypertension treatment, while Control group patients received only antihypertensive treatment.

BP recording, serum lipid profile, echocardiogram for left ventricular function and Doppler study for endothelial function were repeated after 4 weeks in study and control subjects.

\section{RESULTS}

\section{Clinical characteristics}

In Study group: the age of the 15 hypertensive patients ranged from $38-65 y$ rs with a mean of 51.33 yrs \pm 6.72 with $10(66.67 \%)$ males and $5(33.33 \%)$ females. Similarly Control group consisted of 15 hypertensive patients with age ranging between 36-63yrs with a mean of $51.13 \pm 7.29,10(66.67 \%)$ males and $5(33.33 \%)$ females.

The duration of hypertension in Study group ranged between 2-10yrs with a mean of $3.93 y r s \pm 2.71$ while in Control group it ranged between 2-8yr with a mean of $3.86 y r s \pm 2.59$. Both Study and Control groups have 3 newly detected hypertensive.

\section{Routine investigations}

Both in study and control cases routine biochemical investigations-fasting blood sugar, serum creatinine, and serum electrolytes were within normal limits.

X-ray chest (PA view) and ECG revealed cardiomegaly and left ventricular hypertrophy (LVH) in $6(40 \%)$ study cases with duration of hypertension of $\geq 5$ yrs. Similarly Cardiomegaly and LVH were present in 5 (33.33\%) patients of Control group with duration of hypertension of $\geq 6 \mathrm{yrs}$.

\section{Lipid profile}

Dyslipidemia was present in both groups of patients. After 4 weeks of study, the mean total cholesterol in study group decreased significantly $(18.92 \%, \mathrm{P}<0.01)$ from $227 \mathrm{mg} / \mathrm{dl}$ to $184 \mathrm{mg} / \mathrm{dl}$, while in control group mean total cholesterol decreased marginally (4.81\%) from $211 . \mathrm{mg} / \mathrm{dl}$ to $201 \mathrm{mg} / \mathrm{dl}$.

Similarly the mean LDL-C cholesterol in study group decreased significantly $(20.74 \%, \mathrm{P}<0.01)$ from 106 $\mathrm{mg} / \mathrm{dl}$ to $84 \mathrm{mg} / \mathrm{dl}$, while in control group the mean LDL cholesterol decreased insignificantly $(2.99 \%)$ to $99 \mathrm{mg} / \mathrm{dl}$ from 102. $\mathrm{mg} / \mathrm{dl}$. So also the decrease of triglycerides in study group was significant $(11.75 \%, \mathrm{P}<0.01)$ from $159 \mathrm{mg} / \mathrm{dl}$ to $140 \mathrm{mg} / \mathrm{dl}$ while this was insignificant $(1.38 \%)$ in control cases which decreased to $156 . \mathrm{mg} / \mathrm{dl}$ from $158 \mathrm{mg} / \mathrm{dl}$. The initial mean HDL cholesterol in study group was $41 \mathrm{mg} / \mathrm{dl}$ and after 4 weeks it has increased significantly $(13.94 \%, \mathrm{P}<0.01)$ to $47 \mathrm{mg} / \mathrm{dl}$ while in control group the mean HDL cholesterol increased marginally (3.39\%) to $42 \mathrm{mg} / \mathrm{dl}$ from $41 \mathrm{mg} / \mathrm{dl}$.

In study group the significant decrease in total cholesterol, LDL-C and triglycerides and increase in HDL-C was more in patients with duration of hypertension of $<5 y$ rs as compared to patients with duration of hypertension of $\geq 5$ yrs (Table 1 ).

Table 1: Lipid profile initial vs after 4 weeks.

\begin{tabular}{|c|c|c|c|}
\hline \multicolumn{2}{|c|}{$\begin{array}{l}\text { LIPID Parameters } \\
\text { (mean values mg/dl) }\end{array}$} & Study group & $\begin{array}{l}\text { Control } \\
\text { group }\end{array}$ \\
\hline \multirow{3}{*}{$\begin{array}{l}\text { Total } \\
\text { cholesterol }\end{array}$} & $\begin{array}{l}\text { Initial } \\
\text { value }\end{array}$ & $227 \mathrm{mg} / \mathrm{dl}$ & $211 \mathrm{mg} / \mathrm{dl}$ \\
\hline & $\begin{array}{l}\text { After } 4 \\
\text { wks }\end{array}$ & $184 \mathrm{mg} / \mathrm{dl}$ & $201 \mathrm{mg} / \mathrm{dl}$ \\
\hline & $\%$ of $\boldsymbol{v}$ & $\begin{array}{l}18.92 \%(\mathrm{P} \\
<0.01)\end{array}$ & $4.81 \%$ \\
\hline \multirow{3}{*}{ LDL-C } & $\begin{array}{l}\text { Initial } \\
\text { value }\end{array}$ & $106 \mathrm{mg} / \mathrm{dl}$ & $102 \mathrm{mg} / \mathrm{dl}$ \\
\hline & $\begin{array}{l}\text { After } 4 \\
\text { wks }\end{array}$ & $84 \mathrm{mg} / \mathrm{dl}$ & $99 \mathrm{mg} / \mathrm{dl}$ \\
\hline & $\%$ of $v$ & $\begin{array}{l}20.74 \%(\mathrm{P} \\
<0.01)\end{array}$ & $2.99 \%$ \\
\hline \multirow{3}{*}{ HDL-C } & $\begin{array}{l}\text { Initial } \\
\text { value }\end{array}$ & $41 \mathrm{mg} / \mathrm{dl}$ & $41 \mathrm{mg} / \mathrm{dl}$ \\
\hline & $\begin{array}{l}\text { After } 4 \\
\text { wks }\end{array}$ & $47 \mathrm{mg} / \mathrm{dl}$ & $42 \mathrm{mg} / \mathrm{dl}$ \\
\hline & $\%$ of $\uparrow$ & $\begin{array}{l}13.94 \%(P \\
<0.01)\end{array}$ & $3.39 \%$ \\
\hline \multirow{3}{*}{$\begin{array}{l}\text { Triglycerid } \\
\text { es }\end{array}$} & $\begin{array}{l}\text { Initial } \\
\text { value }\end{array}$ & $159 \mathrm{mg} / \mathrm{dl}$ & $158 \mathrm{mg} / \mathrm{dl}$ \\
\hline & $\begin{array}{l}\text { After } 4 \\
\text { wks }\end{array}$ & $140 \mathrm{mg} / \mathrm{dl}$ & $156 \mathrm{mg} / \mathrm{dl}$ \\
\hline & $\%$ of $\boldsymbol{v}$ & $\begin{array}{l}11.75 \%(\mathrm{P} \\
<0.01)\end{array}$ & $1.38 \%$ \\
\hline
\end{tabular}

\section{Endothelial function}

In study group the reactive hyperemia induced brachial artery diameter improved significantly $(15.57 \%, \mathrm{P}<0.01)$ to $4.23 \mathrm{~mm}$ from $3.66 \mathrm{~mm}$, while in control group there was marginal increase $(3.24 \%) 3.70 \mathrm{~mm}$ to $3.82 \mathrm{~mm}$.

In study group Flow mediated brachial artery diameter $(\mathrm{FMD} \%)$ increased significantly $(11.39 \%, \mathrm{P}<0.01)$ from $7.37 \%$ to $19.18 \%$, while in control group this increased marginally $(1.07 \%)$ from $7.50 \%$ to $8.57 \%$. 
Similarly patients with long standing hypertension ( $\geq 5 \mathrm{yrs}$ ) show less response to \%FMD in both study and control groups (Figure 1 and Table 2).

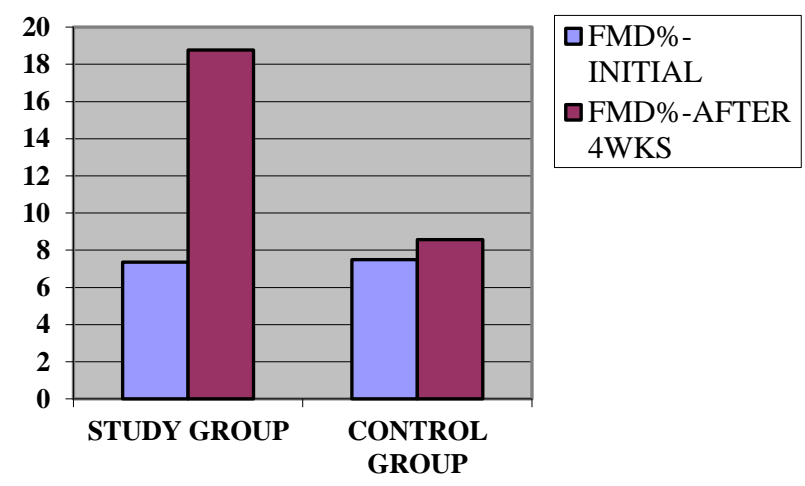

Figure 1: Endothelial function: FMD \% in study and control cases.

Table 2: Endothelial function initial vs after 4 weeks.

\begin{tabular}{|c|c|c|c|}
\hline Parameter & & $\begin{array}{l}\text { Study } \\
\text { group }\end{array}$ & $\begin{array}{l}\text { Control } \\
\text { group }\end{array}$ \\
\hline \multirow{3}{*}{$\begin{array}{l}\text { Mean Brachial } \\
\text { artery } \\
\text { Diameter (mm) }\end{array}$} & $\begin{array}{l}\text { Initial } \\
\text { value }\end{array}$ & 3.42 & 3.45 \\
\hline & $\begin{array}{l}\text { After } 4 \\
\text { weeks }\end{array}$ & 3.55 & 3.52 \\
\hline & $\%$ of $\uparrow$ & $3.82 \%$ & $2.02 \%$ \\
\hline \multirow{3}{*}{$\begin{array}{l}\text { Mean Brachial } \\
\text { artery } \\
\text { diameter after } \\
\text { reactive } \\
\text { hyperemia }(\mathrm{mm})\end{array}$} & Initial & 3.66 & 3.70 \\
\hline & $\begin{array}{l}\text { After } 4 \\
\text { weeks }\end{array}$ & 4.23 & 3.82 \\
\hline & $\%$ of $\uparrow$ & $\begin{array}{l}15.57 \%(\mathrm{P} \\
<0.01)\end{array}$ & $3.24 \%$ \\
\hline \multirow{3}{*}{$\begin{array}{l}\text { Mean Flow } \\
\text { Mediated } \\
\text { Dilatation (FMD } \\
\text { in \%) } \\
\text { of Brachial } \\
\text { artery }\end{array}$} & Initial & $7.37 \%$ & $7.50 \%$ \\
\hline & $\begin{array}{l}\text { After } 4 \\
\text { weeks }\end{array}$ & $19.18 \%$ & $8.57 \%$ \\
\hline & $\%$ of & $\begin{array}{l}11.39 \%(\mathrm{P} \\
<0.01)\end{array}$ & $1.07 \%$ \\
\hline
\end{tabular}

\section{Left ventricular function}

The mean LV systolic function (EF) in study group was $54.6 \%$ which improved significantly $(10.73 \%$, P: <0.01) to $60.65 \%$ and mild $\mathrm{LV}$ systolic dysfunction $(\mathrm{EF}<50)$ detected initially in $2(13.33 \%)$ patients was normalized with improvement in EF to $>50 \%$. However in control group it marginally improved $(1.47 \%)$ to $54.86 \%$ from $54.06 \%$ and mild LV systolic dysfunction $(\mathrm{EF}<50)$ detected initially in $2(13.33 \%)$ patients was not improved.

Initial assessment of $\mathrm{LV}$ diastolic function detected diastolic dysfunction in $12(80 \%)$ patients each of study and control groups. However in study group LV diastolic function was normalized in $7(46.67 \%)$ patients and 5 $(33.33 \%)$ patients showed improvement from moderate to mild diastolic dysfunction after 4 weeks. However in control group there was no improvement in diastolic dysfunction.

The significant improvement of LV systolic and diastolic functions after therapy with atorvastatin in study group was more in patients with duration of hypertension <5yrs as compared to patients with duration of $\geq 5$ yrs (Figure 2 , 3 and 4 and Table 3 ).

Table 3: LV function initial Vs after 4 weeks.

\begin{tabular}{|c|c|c|c|}
\hline Parameters & & $\begin{array}{l}\text { Study } \\
\text { group }\end{array}$ & $\begin{array}{l}\text { Control } \\
\text { group }\end{array}$ \\
\hline \multirow{3}{*}{$\begin{array}{l}\text { LV Systolic } \\
\text { Function } \\
(\text { EF \%) }\end{array}$} & Initial & 54.6 & 54.06 \\
\hline & After 4 wks & 60.46 & 54.86 \\
\hline & $\%$ of $\uparrow$ & $\begin{array}{l}10.73 \% \\
(P:<0.01)\end{array}$ & $1.47 \%$ \\
\hline \multirow{2}{*}{$\begin{array}{l}\text { LV Systolic } \\
\text { dysfunction } \\
(\mathrm{EF}<50 \%)\end{array}$} & Initial & $2(13.33 \%)$ & $2(13.33 \%)$ \\
\hline & After 4 wks & nil & $2(13.33 \%)$ \\
\hline \multirow{2}{*}{$\begin{array}{l}\text { LV } \\
\text { Diastolic } \\
\text { dysfunction } \\
\text {-mild }\end{array}$} & Initial & $7(66.67 \%)$ & $8(53.33 \%)$ \\
\hline & After 4 wks & $5(33.33 \%)$ & $8(53.33 \%)$ \\
\hline \multirow{2}{*}{$\begin{array}{l}\text { LV } \\
\text { Diastolic } \\
\text { dysfunction } \\
\text {-moderate }\end{array}$} & Initial & $5(33.33 \%)$ & $4(26.67 \%)$ \\
\hline & After 4 wks & nil & $4(26.67 \%)$ \\
\hline
\end{tabular}

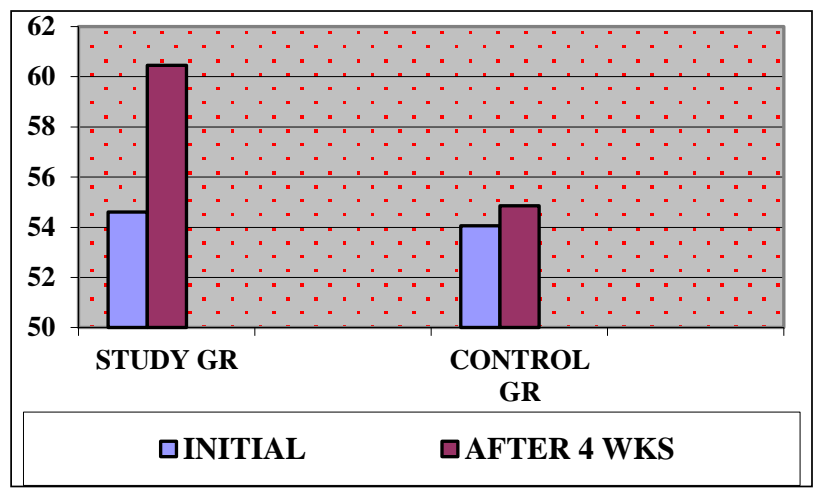

Figure 2: LV systolic function (EF \%) in study and control cases.

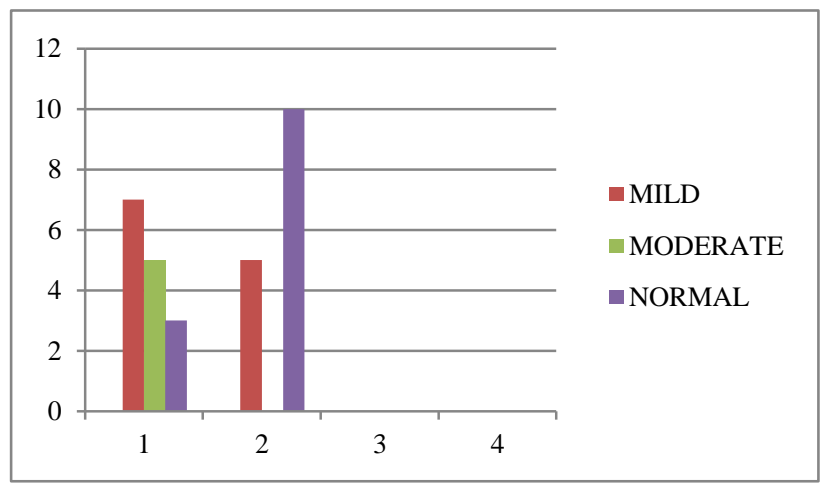

Figure 3: LV diastolic dysfunction in study cases. 


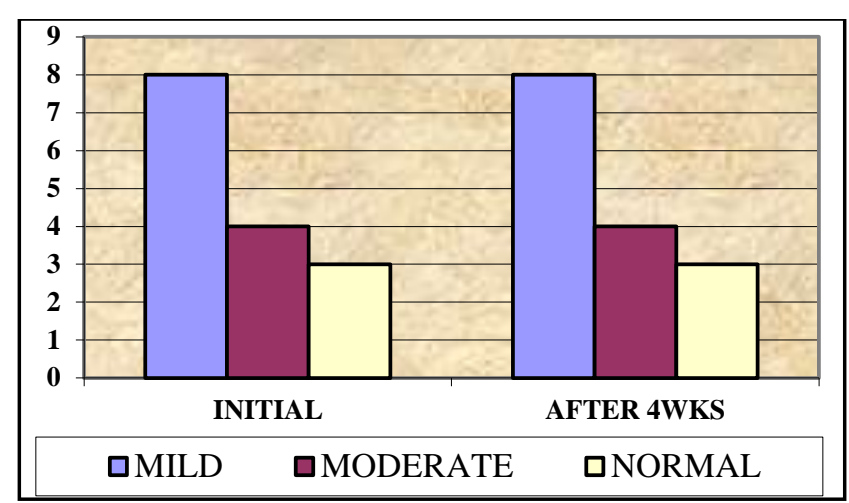

Figure 4: LV diastolic dysfunction in control cases.

\section{Blood pressure}

The mean systolic BP in study group decreased significantly $(12.03 \%)$ to $131 \mathrm{mmHg}$ from $149 \mathrm{~mm} \mathrm{Hg}$ after 4 wks of atorvastatin and concurrent hypertension treatment, while in control group it decreased marginally (6.25\%) from $149 \mathrm{mmHg}$ to $140 \mathrm{~mm} \mathrm{Hg}$ after 4 weeks of hypertension treatment but without atorvastatin therapy.

Similarly the mean diastolic BP in study group was $90 \mathrm{mmHg}$ which decreased significantly (10.29\%, $\mathrm{P}<0.01$ ) from $90 \mathrm{mmHg}$ to $81 \mathrm{~mm} \mathrm{Hg}$, while in control group it decreased marginally $(0.74 \%)$ from $90 \mathrm{mmHg}$ to 89mmHg (Table 4).

Table 4: Blood pressure (BP) initial Vs after 4 weeks.

\begin{tabular}{|c|c|c|c|}
\hline \multicolumn{2}{|c|}{ Parameters } & Study group & $\begin{array}{l}\text { Control } \\
\text { group }\end{array}$ \\
\hline \multirow{3}{*}{$\begin{array}{l}\text { Mean } \\
\text { systolic } \\
\text { BP } \\
(\mathrm{mmHg})\end{array}$} & $\begin{array}{l}\text { Initial } \\
\text { value }\end{array}$ & 149 & 149 \\
\hline & $\begin{array}{l}\text { After } 4 \\
\text { weeks }\end{array}$ & 131 & 140 \\
\hline & $\%$ of $\boldsymbol{\nu}$ & $12.03 \%(\mathrm{P}:<0.01)$ & $6.25 \%$ \\
\hline \multirow{3}{*}{$\begin{array}{l}\text { Mean } \\
\text { diastolic } \\
\mathrm{BP} \\
(\mathrm{mmHg})\end{array}$} & Initial & 90 & 90 \\
\hline & $\begin{array}{l}\text { After } 4 \\
\text { weeks }\end{array}$ & 81 & 89 \\
\hline & $\%$ of $\downarrow$ & $10.29 \%(\mathrm{P}:<0.01)$ & $0.74 \%$ \\
\hline
\end{tabular}

\section{DISCUSSION}

\section{Lipid effects of statins}

In the present study there was significant effect on lipid profile in study cases that were given atorvastatin for 4 weeks with concurrent treatment of hypertension. Similar observations were reported by ASCOT, MIRACL, PROVE-IT and CURVES trials. ${ }^{5-8}$

\section{Non-lipid effects of statins: on endothelial function}

Present study indicates endothelial dysfunction in all the patients of both the groups (FMD\% in Study gr: $7.37 \%$, Control gr: $7.50 \%$, Normal: is $\geq 18.5 \%$ ) which is similar to previous studies of Kelm M, et al, Iiyama et al, Li J et al, Hunan et al and Atkov et al. ${ }^{9-13}$ The pathogenesis for endothelial dysfunction in hypertensive patients is due to;

1. Physical stress (shear stress of hypertension) that can alter hemorrheology, and cause mechanical damage to endothelial cells leading to endothelial dysfunction.

2. Similarly dyslipidaemia is associated with the loss of endothelium dependent dilatation as oxidized LDL and small dense LDL affect the endothelial NO bioavailability. ${ }^{14}$ So also remnant particles formed from chylomicrons and VLDL are highly atherogenic and are associated with endothelial dysfunction and reduced NO. ${ }^{15}$

In the present study patients treated with atorvastatin for 4 weeks in study group showed greater increase in FMD \% as compared to patients without atorvastatin in control group (18.76 Vs $8.57 \%)(\mathrm{P}<0.01)$. The significant change in the lipid profile with atorvastatin therapy has contributed to the drastic improvement in the endothelial function.

This potential effect of statins in the improvement of endothelial function in the present study was also reported by previous studies of Lueng WH et al in hypercholesterolemic patients, O' Driscoll $\mathrm{G}$ et al with simvastatin, Treasure $\mathrm{CB}$ et al with lovastatin and Egashira K et al with pravastatin. ${ }^{16-19}$

\section{Non-lipid effects of statins: on lv function}

In the present study there was LV dysfunction in most of the patients in both groups which was also reported in previous studies of Frohlich ED et al, Dunn FG et al, Dreslinski GR et al, Inouye I et al and Fouad FM et al. $^{20-24}$

The significant improvement in LV systolic and diastolic functions in the study cases $(\mathrm{P}<0.01)$ as compared to control group in the present study is due to;

1. Significant improvement in endothelial function and

2. Significant decrease in systolic and diastolic BP after therapy with atorvastatin and concurrent use of antihypertensives.

\section{Non-lipid effects of statins: on BP}

The significant decrease of systolic and diastolic BP $(\mathrm{P}<0.01)$ in the present study in study cases as compared to control group could be due to significant improvement in endothelial function, left ventricular function and lipid profile.

\section{CONCLUSION}

- $\quad$ Present study showed dyslipidemia, endothelial and ventricular dysfunctions occur in most patients of 
hypertension. Hence all hypertensive patients should be investigated for dyslipidemia besides routine investigations and followed up for brachial artery endothelial function and LV function at least every 3 months.

- $\quad$ Present study showed not only improved lipid profile in hypertensive patients but also improved endothelial and LV functions which resulted in significant reduction of systolic and diastolic BP as compared to controls.

- Hence it is reasonable to treat all hypertensive patients with statins besides concurrent hypertension treatment for the improvement in the lipid profile, endothelial and ventricular functions which is manifested clinically as significant reduction in systolic \& diastolic BP and thereby preventing and reducing complications of hypertension including coronary heart disease, heart failure, stroke and mortality.

- All treatment modalities should be started early as beneficial effects in chronic hypertensive patients are less.

\section{ACKNOWLEDGEMENTS}

Iam thankful to Prof. Ramesh S, Dept of Pharmacology; Prof Vijayalakshmi G, Dept of Pharmacology; Prof. Sudhakar Reddy P, Dept of Cardiology; Prof. Murthy NLN, Dept of Radiodiagnosis; Prof. Rekha C, Dept of Biochemistry, Gandhi Medical College Hospital, Hyderabad, TS. India, for their constant guidance and encouragement in carrying out this study and to all my patients who fully cooperated in conducting this study.

\section{Funding: No funding sources}

Conflict of interest: None declared

Ethical approval: The study was approved by the Institutional Ethics Committee

\section{REFERENCES}

1. Kaplan NM. Systematic hypertension. Mechanisms and Diagnosis. In Braunwald's Heart disease $5^{\text {th }}$ ed. Philadelphia: W. B. Saunders Company. 1997;26:807-40.

2. Chobanian AV, Bakris GL, Black HR. The seventh report of the Joint National Committee on Prevention, Detection, Evaluation, and Treatment of High Blood Pressure: The JNC 7 Report. JAMA 2003;289:2560-72.

3. Rakowskiv H, Appleton C, Chan KL. Canadian consensus recommendations for measurement and reporting of diastolic dysfunction by echocardiography. J Am Soc Echocardiogr. 1996;9:736-60.

4. Celermajer DS, Sorenesen KE, Gooch VM, Spiegelhalter DJ, Miller OI. Noninvasive detection of endothelial dysfunction in children and adults at risk of atherosclerosis. Lancet. 1992;340:1111-15.
5. Sever PS, Dahlof B, Poulter NR. Prevention of coronary and stroke events with atorvastatin in hypertensive patients who have average or lower the average cholesterol concentrations, in the Anglo Scandinavian Cardiac Outcomes Trial-Lipid Lowering Arm (ASCOT-LLA): A multicentre randomized controlled trial. Lancet. 2003;361:114958.

6. Schwartz GG. Effects of atorvastatin on early recurrent ischemic events in acute coronary syndrome. The MIRCL study: a randomized control trial. JAMA. 2001;285:1711.

7. Cannon CP. Intensive versus moderate lipid lowering with statins after acute coronary syndrome: PROVEIT trial. N Eng J Med. 2004;350:1945-504.

8. Jones PH, Kafonek S, Laurora I. Comparative dose efficacy study of atorvastatin with that of lovastatin, pravastatin, simvastatin and fluvastatin in patients with hypercholesterolemia: The CURVES study. Am J Cardiol. 1998;81:582-7.

9. Kelm M, Preik M, Hafner DJ, Strauer BE. Evidence for a multifactorial process involved in the impaired flow response to nitricoxide in hypertensive patients with endothelial dysfunction. Hypertension. 1996;27:346-53.

10. Iiyama K, Nagano M, Yo Y, Nagono N, Kamide K. Impaired endothelial function with essential hypertension assessed by ultrasonography. Am Heart J. 1996;132:77-82.

11. Li J, Zhao SP, Li XP, Zhuo QC, Gao M, Lu SK. Noninvasive detection of endothelial dysfunction in patients with essential hypertension. Int J Cardiology. 1997;61:165-9.

12. Hunan Y, Ke D. Noninvasive detection of endothelial dependent dilation dysfunction in patients with essential hypertension. Xue Xue Bao. 1998;23(6):590-2.

13. Atkovo OY, Balahonova TV, Pogorelova OA. Noninvasive USG Detection of endothelial function. Eur J Ultrasound. 1998:7(1):37-45.

14. Kinlay S, Selwyn AP, Delagrange D. Biological mechanisms for the clinical success of lipid lowering in coronary artery disease and the use of surrogate end points. Curr Opin Lipidol. 1996;7:389-97.

15. Inoue $T$, Saniabadi AR, Matsunaga R. Impaired endothelial dependent acetylcholine induced coronary artery relaxation in patients with high serum remnant lipoprotein particles. Atherosclerosis. 1998;139:363-7.

16. Leung WH, Lau CP, Wong CK. Beneficial effect of cholesterol lowering therapy on coronary endothelium dependent relaxation in hypercholesterolaemic patients. Lancet. 1993;341:1496-1500.

17. O'Driscoll G, Green D, Taylor RR. Simvastatin, an HMG-Coenzyme A reductase inhibitor, improves endothelial function within 1 month. Circulation. 1997;95:1126-31.

18. Treasure CB, Klein JL, Weintraub WS. Beneficial effects of cholesterol lowering therapy on the 
coronary endothelium in patients with coronary artery disease. N Eng J Med. 1995;332:481-7.

19. Egashira K, Hiroka Y, Kai H. Reduction in serum cholesterol with pravastatin improves endothelium dependent coronary vasomotion in patients with hypercholesterolemia. Circulation. 1994;89:2519-24.

20. Frohlich ED, Tarazi RC, Dustan HP. Clinicalphysiological correlations in the development of hypertensive heart disease. Circulation. 1971;4:44655.

21. Dunn FG, Chandraratna P, de Carvalho JGR, Basta LL, Frohlich ED. Pathophsyiologic assessment of hypertensive heart disease with echocardiography. Am J Cardiol. 1977;39:789-95.

22. Dreslinski GR, Frohlich ED, Dunn FG, Messerli FG, Suarez DH, Reisin E. Echocardiographic diastolic ventricular abnormality in hypertensive heart disease:
Atrial emptying index. Am J Cardiol. 1981;47:108790.

23. Inouye I, Massie B, Loge D, Topic N, Silverstein D, Simpson P. Abnormal left ventricular filling: An early finding in mild to moderate systemic hypertension. Am J Cardiol. 1984;53:120-6.

24. Fouad FM, Slominski JM, Tarazi RC. Left ventricular diastolic function in hypertension: Relation to left ventricular mass and systolic function. J Am Coll Cardiol. 1984;3:1500-6.

Cite this article as: Shashikala E., Raghawa Rao BNV. Study of lipid and non-lipid effects of statins in hypertensive patients. Int J Basic Clin Pharmacol 2016;5:2452-7. 